\title{
Management Education - The Semitic and Indo-European Languages: Arabic, Russian, Spanish languages
}

\section{Stefania Allegra}

Atlantic International University, Department of Education Faculty, Honolulu, Hawaii, United States

\begin{abstract}
The ability to work in more tasks in every field in life, is a hard goal to achieve. I can affirm with proof that you need to train constantly for it. It means that you have to train the mind and action through the same direction. I've been trained myself in this task with my own personal life experiences. Since I was twenty I've held many important and hard tasks that have changed my mind results.

It's the same in the field of learning, studying and teaching foreign languages. If you don't train almost every day your memorization, it's quite impossible to learn a foreign language. A professional professor in foreign languages is normally used to teach one, two languages or sometimes more, and it's difficult in any case.
\end{abstract}

According to my experience I got the special training to teach many languages, I mean at the same time, to switch from one language to another. So it happens that I teach more languages in the same day and even in the same hour, without any difficulty. It's possible only because my mind is always well trained.

For example, when you change languages, you must remember all skills, from all languages. So when I teach English, German, French, Russian, Arabic, Italian, etc.. It's not easy to train the mind in this way, but you can succeed if you do the right training.

It's important to be conscious about the power of the mind, when we want to learn a foreign language. It's not easy but you must focus on training hard to get true results.

The mistake is to think to learn a language without passion just as chore, this way you will never learn it; passion is the first step in helping the memorization. Then you will find the next step to follow the training of memorization.

Keywords: Psychology, Education, memorization, foreign languages, English language as L2, brain processes, learning languages, English, French, German, Arabic, Russian, Spanish.

\section{Introduction}

Learning and speaking more than one language activates in your mind an open system of looking at world in a different way. When you know a language, you open the mind towards a new culture, habits, and of course a system of writing that is different than your mother tongue. The importance of multilingualism can bring a new consciousness of the foreign languages knowledge.

Teaching a foreign language is normally part of a good background to find success with students. To teach a foreign language is a way of being; it expresses the teacher background at any time.

The Indo-European languages are a language family native to western Eurasia. It includes the most important as English, French, German, Spanish, Italian, Persian, Russian, Sanskrit etc..

The Semitic languages or Syro-Arabian languages are a very important group of languages, they are spoken by more than 330 million people, in fact Arabic is the most spoken with 300 million people, then we have Amharic, Tigrinya, Hebrew, Tigre, Aramaic, Assyrian, Maltese.

The written form started from the 30th century BC, and we find a kind of script that is so called abjads, it comes from the Phoenician alphabet. 1 
It's one of the Arabic alphabet use, so called collation sequences, and the other one is hija. Abjads is the oldest Arabic sequence that omits some or all vowels, while hija is the most common used sequence.

Abjads has got a correspondence position to the Aramaic letter Samekh that has been replaced by the Shin. It's the 21st letter of the Semitic abjads. You find it as $\omega(\operatorname{sh} \bar{i})$ and $\omega(\sin ) .2$

We can remember the abjads in the Hebrew, Arabic, Aramaic languages etc.

The Semitic term was born with the Gottingen School of History and in particular we can remember $\mathrm{Mr}$ August Ludwing von Schlozer. The Semitic term is created to put together a group of languages as Arabic, Aramaic, Hebrew.

In $8^{\text {th }}$ century BC there was an influence to form a number of additional languages, therefore, because of the Cushitic influence, there was a diversification of Semitic languages. 3

The Ancient Semitic languages were spoken by Western Asian people. Their languages were divided in 3 branches, East with Akkadian Empire, Assyria, Babylonia; Central with Northwest Semitic languages and Arabic; and South Semitic languages with Modern South Arabian and Semitic languages. 4

Today the Arabic is the main language because it's spoken in a wide area from Mauritania to Oman, from Iraq to the Sudan.

Arabic is the sixth most spoken language in the world, it is spoken by 422 million people.

Classical Arabic, used in the literary text of the Umayyad and Abbasid from the $7^{\text {th }}$ to $9^{\text {th }}$ century AD, is a religious language because it's the language of the Quran.

One of the most important way to spread a culture, is to be able to speak a foreign language that connects you to a whole population.

\section{The Semitic and Indo-European Languages}

\section{Semitic Languages: a focus on Arabic language}

Semitic languages have systems many particular fields in grammar; phonology and morphology are very old conservative. There are particular of the grammar common to the Semitic languages, as three grammatical numbers as the singular, dual, plural.

Semitic languages have two kind of morphology styles for conjugating verbs. So we have prefix conjugation, where prefix indicates people, and suffix for number and gender. We can distinguish the preterit, perfect, and no past or imperfect, stative. All suffixes are similar to proto-Semitic.

It's important to say that we have Semitic roots that are typically common in Semitic languages, we can distinguish three literal roots. 5

Arabic is a Semitic language, and there are many European languages that borrow many words from Arabic as in Spanish and Sicilian, and further in Catalan, Portuguese, Greek, Bulgarian, Maltese. Arabic influences many other languages like Persian.

Arabic was similar to Aramaic and Hebrew since the medieval times. 6

Arabic has got a type of writing from right to left, with 28 letters, where you find many dots above or below some of this shape, and it's written from right to left, with no capital letters. There are 18 distinct letter shapes, which vary slightly depending on whether they are connected to another letter before or after them.

And it's the language of the Qur'an, the holy book of Islam, it has religious roots too, the dialect of Mecca, and it's well defined classic Arabic. Today it's spoken in Saudi Arabia.

There are several dialects, they are very difficult to understand, and there is also Modern Standard Arabic, that's used in International conferences, books, newspapers, television, etc..

All these different dialects originated in the Arabian Peninsula, and generating differences according to the regions. So it's important to underline the mutual intelligibility relation, that is in linguistics the relationship among dialects, because they can understand each other. It's the linguistic distance among languages. So 
Mutual Intelligibility can be influenced by different factors as various registers, culture, psycho-cognitive traits, etc.. During the changes there was a loss in grammar aspects, in classical Arabic and colloquial Arabic. 7

\section{Indo-European languages: a focus on Russian language}

The Indo-European languages come from Eurasia, including all Europe and Asia. Instead Semitic languages are spoken in the Middle East and North Africa. They came from a single prehistoric language, spoken in Neolithic era. In Bronze age we had a written development of Mycenaean Greek and Anatolian languages, Hittite, Luwian.

The most common Indo-European spoken languages by 3.2 billion people are: Spanish, English, Hindustani, Portuguese, Bengali, Russian, Punjabi, German, French and Marathi.

Spanish gets the influence from Arabic loanwords. It's a romance language, and so called Castilian too, spoken in the Iberian peninsula. We can find in Toledo the first writings of the Spanish language. During the 11th, 12th and 13th centuries the Spanish got the strongest influence of Arabic derivations during the Christian Reconquista. The Arabic language was influenced by Arabized Romance dialects that were spoken in areas under Moorish rule, known today as Mozarabic language.

Today you can consider about four thousand words coming from the Spanish dictionary that got Arabic derivations. 8

Another important foreign language is Russian, it's the seventh most spoken language, in Russia, Ukraine and Belarus, Kazakhstan, Kyrgyzstan and we can find Russian in Mongolia and Israel too. It's the most spoken of the Slavic language and seventh most spoken language in the world.

Russian is part of the Balto-Slavic branch. It's one of the six United Nations official languages too; and it's also a very important language for United States Intelligence Community.

It's an Indo-European language and it's an East Slavic language.

We can find Russian as a sort of bilingualism as in eastern Ukraine with Surzhyk, i.e. a mix of Ukrainian sociolect and Russian languages. And a mix language so called Trasianka, in Belarus.

Modern Russian had an important influence from an East Slavic Old Novgorod dialect. Russian was also called, "Great Russian" and then "White Russian" and Ukrainian, and later "Little Russian". Russian language was influenced by the Slavonic Church.

\section{Indo-European languages: a focus on Spanish language}

Spanish language is an Indo-European and Romance language. It's one of the most spoken languages in the world, above all in Americas and Spain. 9

It's very near to the Latin language, with ancient Greek roots and Arabic roots during the Al-Andalus era in the Iberian peninsula. 10

Spanish is also called Castellano, it comes from the Latin word Castellanus. In 1978 the Spanish constitution called Castellano to be the official language.

It got many other influences from languages Italian, French, Portuguese, Galician, Occitan, Sardinian, and became the official language of Andalusia Romance, Quechua, Nahuatl, and other American indigenous languages.

Spanish is also called Castilian.

Spanish is not a very difficult language, it's similar to Italian in grammar parts, as a special sound in pronunciation, has a very important rhythm, that can help you to learn easily.

Spanish has elements of West Iberian Romance languages as Asturian, Aragonese, Galician, Ladino, Leonese, Mirandese, and Portuguese. 11 
Spanish is spoken in many countries: Mexico, Colombia, Spain, Argentina, Peru, Venezuela, Chile, Ecuador, Guatemala, Cuba, Bolivia, Dominican Republic, Honduras, Paraguay, El Salvador, Nicaragua, Costa Rica, Panama, Uruguay and Equatorial Guinea. 12

\section{Conclusion}

In conclusion, I underline the importance of the Arabic language as one of the most interesting languages, that brought a strong influence, as it was for Russian and Spanish too. Language is a representation of the natural collective memory, to affirm its own identity.

We can remember one of the most important representative in the development of linguistics and semiology, Yeats Butler William, he said: "A language represents the natural collective memory of a population: in order to take possession of a new linguistic instrument, if it loses contact with its most ancient means of expression, it becomes completely unable to recognize itself in its own traditions: how can it affirm one's identity? " 13

\section{Notes}

1. https://en.wikipedia.org/wiki/Semitic_languages, visited on May 09, 2020.

2. https://en.wikipedia.org/wiki/Phoenician_alphabet visited on May 09, 2020.

3. https://en.wikipedia.org/wiki/Semitic_languages visited on May 16, 2020.

4. https://en.wikipedia.org/wiki/Ancient_Semitic-speaking_peoples, visited on June 10, 2020.

5. https://en.wikipedia.org/wiki/Semitic languages, visited on June 30, 2020.

6. https://en.wikipedia.org/wiki/Indo-European_languages, visited on July 1, 2020.

7. https://en.wikipedia.org/wiki/Mutual_intelligibility, visited on August 22, 2020

8. https://en.wikipedia.org/wiki/Russian_language, visited on August 12, 2020.

9. https://en.wikipedia.org/wiki/Spanish_language, visited on August 13, 2020.

10. https://en.wikipedia.org/wiki/Mutual intelligibility, visited on August 22, 2020

11. https://en.wikipedia.org/wiki/Varieties_of_Arabic, visited on August 15, 2020

12. https://en.wikipedia.org/wiki/Arabic_language_influence_on_the_Spanish_language, visited on August 1, 2020.

13. https://en.wikipedia.org/wiki/Spanish_as_a_second_or_foreign_language, visited on August 15, 2020

14. https://le-citazioni.it/frasi/548621-william-butler-yeats-una-lingua-rappresenta-la-memoriacollettiva-natu/, visited on August 17, 2020.

\section{Biography}

Stefania Allegra was born on January 6th, 1973 in Taormina (ME) Italy, where she currently lives. She studied and lived in Vienna Austria. She felt a very important connection with the Nordic life. In fact, she has Nordic DNA discovered through the DNA researches. She graduated in Foreign languages and Modern Literatures. Afterward she received several Masters, i.e. Master in International Human Resources; Master in Hotel \& Resort Management; Master in Interpretation for Parliamentary Interpreters and translators and International Organizations; Master in teaching Oriental, rare and Foreign languages; Master in Business Administration (MBA).

She received her $\mathrm{PhD}$ - Doctor in philosophy in Management Education and Business Management at AIU University USA.

She received her Post Doctorate of Management Education and Business Management and Teaching Habilitation CUM LAUDE HONORS- AIU University USA.

She has been managing the Nuova ATENA company in Italy where she teaches Administration and Management at all levels and Foreign and rare Languages too. She has been teaching in university in the degree course for interpreters and translators. She teaches in different foreign and rare languages.

She has Teaching Habilitation in these fields:

- Management, Business, Administration;

- Management Education in Teaching and Learning a Foreign Language; 
- Management Education in Teaching Foreign Languages and Literature;

- Management Education in Teaching Translation and Interpreting;

- Management Education in Teaching Linguistic and Applied Linguistic;

- Management Education in Teaching Business Administration Management.

She is Entrepreneur (www.groupnuovaatena.com), Business Administration and Management Professor, Foreign languages Professor and Linguist, Court translator and Interpreter, Conference Interpreter, Writer, Literary Agent. She's a Scientific Researcher Professor. She is a Martial and Yoga Teacher (www.allegradojo.com).

She has been a professional writer since 2006.

\section{Books Publications}

1. S. Allegra, La psicologia dello yoga applicata al parto - Mursia, 2006 video http://www.youtube.com/watch?v=7hywunYBa9c

http://www.vaitaormina.com/taormina-stefania-allegra-e-i-suoi-libri-sullo-yoga.html

2. S. Allegra, Grossesse et Yoga-pratique, physiologie et psychologie appliqué à la femme enceintePréface de Geeta Iyengar -Les Editions de l'Eveil-Budo Editions, France, 2012

http://www.budo.fr/livres?page=shop.product_details\&flypage=vmj_estore.tpl\&category_id=32\&produc $\underline{\mathrm{t} i \mathrm{id}=415}$;

3. S. Allegra, Come scoprire ed esprimere la propria forza vitale. Il Ki o Prana, Armando Curcio Editore, 2018 (The life force. The KI or PRANA. How to discover your life force. In honour of Angelo D’Arrigo. Angelo D’Arrigo Preface - Stefania Allegra).

\section{LIVE VIDEO}

Armando Curcio Editor- THE SELF ESTEEM on July 16, 2020 LIVE VIDEO

https://youtu.be/X9QLLRB7qs8 THE SELF ESTEEM - L'\#ioPensante with Dr. Anna Gentilini, Adult Editorial Director Armando Curcio Editor, and Prof. Stefania Allegra, Oriental Culture Expert

Discover more about the Life Force! https://curciostore.com/libreria/come-scoprire-edesprimere-la-propria-forza-vitale-il-ki-o-prana/

Stefania Allegra- Come scoprire ed esprimere la propria forza vitale. Il Ki o Prana- Armando Curcio Editor (How to express the Life Force. Ki or Prana).

\section{BOOK PRESENTATIONS}

Rome Mondadori on November 8, 2019

https://youtu.be/aFqpzI7Bsfw

MONDADORI SHORT VIDEO

\section{https://youtu.be/LTXKYVMEmy0}

MONDADORI LONG VIDEO

https://eventi.mondadoristore.it/it/event/2019/11/08/stefania-allegra-presenta-il-libro-come-scoprire-edesprimere-la-propr/8775/ 
Rome EUR La Nuvola on December 6, 2019 -The author meets the audience and signs books. https://youtu.be/eLcxXt9Gm1E

EVENT SHORT VIDEO

https://youtu.be/1RxvXuov 38

EVENT BOOK SIGNING FULL VIDEO

https://www.youtube.com/watch?v=xjue6WJNyfM Video book presentation Castelmola Taormina (ME) Italy on October 28, 2018

https://www.vaitaormina.com/taormina-presentato-il-libro-di-stefania-allegra-armando-curcio-editore/

Other on-going publications

\section{WORK IN PROGRESS}

Next book publication "La psicologia dello yoga applicata al parto", in other foreign languages (work in progress).

Next book publication La forza vitale. Il "Ki" o "Prana". Come scoprire la propria forza vitale. In onore di Angelo D'Arrigo. Prefazione di Angelo D'Arrigo - Stefania Allegra- Armando Curcio Editore, in other foreign languages (work in progress).

Next new book publication work in progress

\section{SCIENTIFIC ARTICLES}

-Scientific article: "The variability in Management according to the Quantum Physic".

Stefania Allegra, Atlantic International University Department of Education Faculty, USA

International Journal of Scientific Research and Management (IJSRM)

||Volume||06||Issue||08||Pages||EM-2018-646-249||2018\|

Website: www.ijsrm.in ISSN (e): 2321-3418

Index Copernicus value (2015): 57.47, (2016):93.67,

DOI: $10.18535 / \mathrm{ijsrm} / \mathrm{v} 6 \mathrm{i} 8 . \mathrm{em} 03$

Article Date Published : 27 August 2018 | Page No.: EM-2018-646-249 | Google Scholar

DOI https://doi.org/10.18535/ijsrm/v6i8.em03

https://www.ijsrm.in/index.php/ijsrm/article/view/1719/1585

https://www.ijsrm.in/index.php/ijsrm/article/view/1719\#title0

- Scientific article: "Management education in teaching at degree, PhD and Post Doctorate students":

Stefania Allegra, Atlantic International University Department of Education Faculty, USA

International Journal of Scientific Research and Management (IJSRM) 
||Volume||07||Issue||01||Pages||EM-2019-947-951||2019||

Website: www.ijsrm.in ISSN

Index Copernicus value (2016): 93.67, (2017):89.90,

DOI: $10.18535 / \mathrm{ijsrm} / \mathrm{v} 7 \mathrm{i} 1 . \mathrm{em} 02$

Article Date Published : 16 January 2019 | Page No.: 947-951 | Google Scholar

DOI: https://doi.org/10.18535/ijsrm/v7i1.em02

https://ijsrm.in/index.php/ijsrm/article/view/1988/1698

https://ijsrm.in/index.php/ijsrm/article/view/1988

- Scientific article: Management Education in teaching and learning a Foreign Language, in particular English language. Teaching Foreign Languages at university, PhD and Post PhD and primary and secondary schools at all levels.

Stefania Allegra, Atlantic International University Department of Education Faculty, USA

International Journal of Scientific Research and Management (IJSRM)

||Volume||07||Issue||03||Pages||EL-2019-953-958||2019|| Website: www.ijsrm.in

ISSN (e): 2321- 3418 Index Copernicus value (2016): 93.67, (2017):89.90,

Article Date Published : 22 March 2019 | Page No.: 953-958 | Google Scholar

DOI https://doi.org/10.18535/ijsrm/v7i3.el05

http://www.ijsrm.in/index.php/ijsrm/article/view/2129

http://www.ijsrm.in/index.php/ijsrm/article/view/2129/1744

-Scientific article: Management Education - The philosophy of Education, Stefania Allegra,

Stefania Allegra, Atlantic International University Department of Education Faculty, USA

International Journal of Scientific Research and Management (IJSRM)

||Volume||07||Issue||06||Pages||EL-

2019-1064-1068||2019|| Website: www.ijsrm.in ISSN (e): 2321-3418

DOI: $10.18535 / \mathrm{ijsrm} / \mathrm{v} 7 \mathrm{i} 6 . e 101$

Article Date Published : 11 June 2019 | Page No.: EL-2019-1064-1070 | Google Scholar

DOI https://doi.org/10.18535/ijsrm/v7i6.el01

https://ijsrm.in/index.php/ijsrm/article/view/2238

https://ijsrm.in/index.php/ijsrm/article/view/2238/18

-Scientific Article: Management Education - The Psychology of the English Language the Importance of Sport, In Learning a Foreign Language, Stefania Allegra,

Stefania Allegra, Atlantic International University Department of Education Faculty, USA 
International Journal of Scientific Research and Management (IJSRM)\|

Volume ||08||Issue||04||Pages||EM-2020-1731-1737||2020||Website: www.ijsrm.in ISSN (e): 2321-3418

DOI: $10.18535 / \mathrm{ijsrm} / \mathrm{v} 8 \mathrm{i} 04 . \mathrm{em} 05$

Article Date Published : 28 April 2020 | Page No.: 1731-1738 | Google Scholar

DOI https://doi.org/10.18535/ijsrm/v8i04.em05

https://ijsrm.in/index.php/ijsrm/article/view/2690

She is in progress about other next publications.

Prof. Dr. Allegra Stefania photo

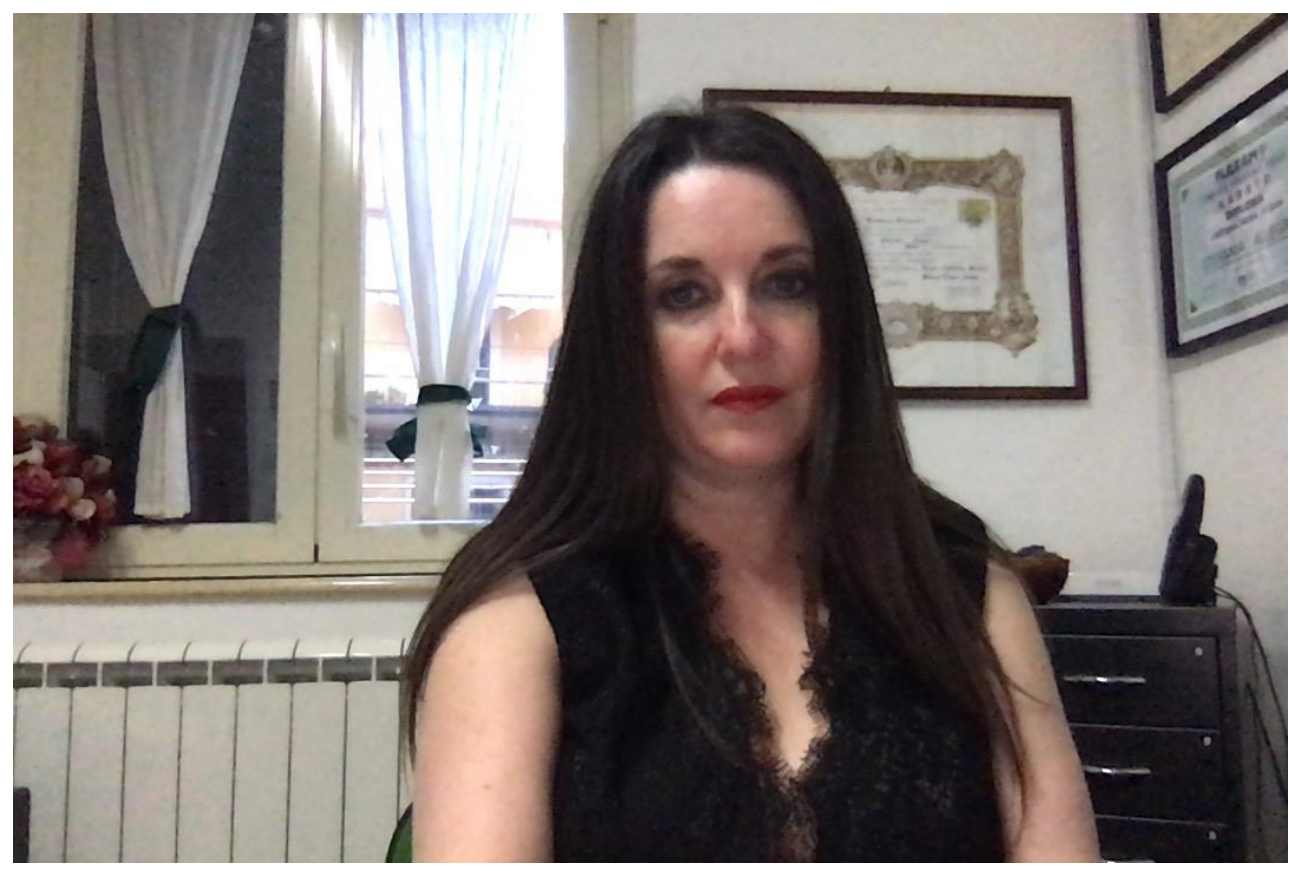

\section{ACKNOWLEDGEMENTS}

I would like to thank the Atlantic International University, Department of Education Faculty, Honolulu, Hawaii, United State, and in particular to Dr Jose Mercado, Chairman of the Board of Trustees.

A special thanks to the Fijlkam Federation President of the Karate in Sicily, Dr. Mallia Giovanni.

A special thanks to the Bank Director Dr. Intelisano Santo, Credito Cooperativo di Pachino.

Also thank you to Mr. Dler Anwar Nuradden, Director of Research \& Training in Erbil- Iraq, for his dedication without asking anything in return, and an important help in my Arabic language and research studies.

A particular thanks to Dr. Hervé Arseneau, Intrapreneur, Investissements Madisco, Beresford, NB, Canada.

Thanks to my professional colleagues.

Thanks to my son Damian and family. 


\section{References}

\section{Bibliography}

[1.] Beeston, A. F. L. The Arabic Language Today. Washington, DC: Georgetown University Press, 2006.

[2.] Blau, Joshau. A Handbook of Early Middle Arabic. Jerusalem: Max Schloessinger Memorial Foundation, Hebrew University of Jerusalem, 2002.

[3.] Fück, Johann. Arabiya: Untersuchungen zur arabischen Sprach-und Stilgeschichte. Berlin: Akademie-Verlag, 1950.

[4.] Holes, Clive. Modern Arabic: Structures, Functions, and Varieties. Rev. ed. Washington, DC: Georgetown University Press, 2004.

[5.] Owens, Jonathan. A Linguistic History of Arabic. Oxford and New York: Oxford University Press, 2006.

[6.] Shah, Mustafa. "The Arabic Language." In The Islamic World. Edited by Andrew Rippin, 261277. London and New York: Routledge, 2008.

[7.] Stetkevych, Jaroslav. The Modern Arabic Literary Language: Lexical and Stylistic Developments. Chicago and London: University of Chicago Press, 2006.

[8.] Versteegh, Kees. The Arabic Language. Edinburgh: Edinburgh University Press, 2001.

[9.] Zwettler, Michael. The Oral Tradition of Classical Arabic Poetry: Its Character and Implications. Columbus: Ohio State University Press, 1978.

[10.] Baldi, Philips. The Foundations of Latin, Mouton de Gruyter, 2002.

[11.] Bauer, Brigitte. Archaic Syntax in Indo-European: The Spread of Transitivity in Latin and French, Mouton de Gruyter, 2000.

[12.] Cooper, Robert L. Language planning and social change. Cambridge: Cambridge University Press, 1989.

[13.] Fortson, Benjamin W. Indo-European language and culture: an introduction. Wiley-Blackwell, 2004.

[14.] Jasanoff, Jay H. Hittite and the Indo-European verb. Oxford University Press, 2005.

[15.] Kerns, J. Alexander. A sketch of the Indo-European finite verb. Brill, 1972.

[16.] Krahe, Hans. Lingüística indoeuropea. Madrid: CSIC, 1953.

[17.] Kortlandt, Frederik Herman Henri: Italo-Celtic origins and prehistoric development of the Irish language. Rodopi, 2007.

[18.] Lazzeroni, Romano. La cultura indoeuropea. Bari: Gius, Laterza \& Figli, 1998

[19.] Lehmann, W.P.Proto-Indo-European Phonology. Austin: University of Texas Press and Linguistic Society of America, 1952

[20.] Lehmann, W.P. A Reader in Nineteenth-Century Historical Indo-European Linguistics. Bloomington: Indiana UP, 1967 